\section{Sericulturist's lung disease: hypersensitivity pneumonitis related to silk production}

\author{
Tsugio Nakazawa, Yoshio Umegae
}

\begin{abstract}
Hypersensitivity pneumonitis developed in a woman engaged in the production of silk, inhalation of silkworm antigens producing several features of the disease.
\end{abstract}

Gunma University School of Medicine, Gunma, Japan T Nakazawa

Professor, College of Medical Care and Technology

Y Umegae

Teaching associate, First Department of Internal Medicine

Address for reprint requests: Dr T Nakazawa, 3-39-15 Maebashi, Gunma, Japan (371).

Accepted 21 September 1989

Sericulture, the production of silk, is an important industry in Japan. Sericulturists buy silkworm eggs, from which larvae are hatched and allowed to mature. The mature larvae are put on cocooning racks, where they spin cocoons and develop into chrysalids. During this time the ripe larvae excrete urine and faeces. The cocoons are gathered and selected by sericulturists, and selected cocoons are taken to the silk factory to be spun into yarn and to make

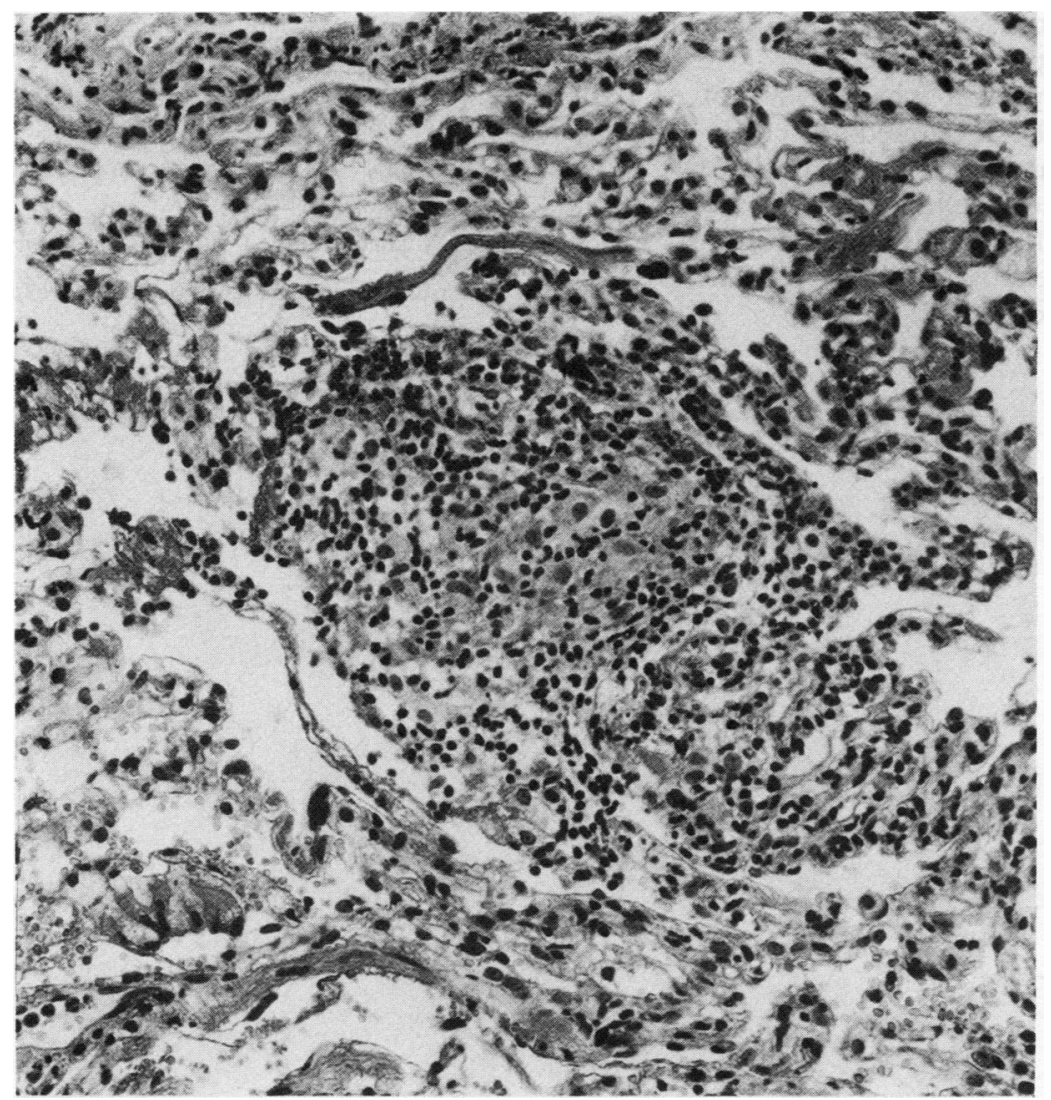

Figure 1 Micrograph of lung tissue showing an epithelioid cell granuloma in the interstitium. (Haematoxylin and eosin.) raw silk. During these processes, especially cocoon selection, the small building is filled with dust, including fluff from the cocoons and dried secretions from the ripe larvae. Workers are exposed to and inhale these antigens. ${ }^{1}$

Case report

A 48 year old woman, who had engaged in sericulture for more than 20 years, was admitted to hospital because of cough, sputum production, exertional dyspnoea, slight fever, and weight loss. The symptoms developed several hours after sericultural work and did not appear when she was not working. On admission physical examination revealed fine crackles in both lower lung fields and slight peripheral cyanosis. Laboratory investigations showed a raised erythrocyte sedimentation rate (40 $\mathrm{mm}$ in one hour), C reactive protein $(t+$ ), leucocytosis $\left(9.0 \times 10^{9} / 1\right)$ and increased lactic dehydrogenase activity $(419 \mathrm{U} / 1)$. Chest radiography showed diffuse fine nodular infiltrates in both lower lung fields. Pulmonary function tests showed a low vital capacity (VC: $74^{\circ}$ o predicted) and carbon monoxide transfer factor (TLCO: $55 \%$ predicted), and arterial hypoxaemia (oxygen tension $\left(\mathrm{PaO}_{2}\right) 9.3 \mathrm{kPa}$ carbon dioxide tension $\left(\mathrm{PaCO}_{2}\right) 4.5 \mathrm{kPa}, \mathrm{pH}$ $7 \cdot 35)$ at rest. The serum IgA concentration was raised $(3.4 \mathrm{~g} / \mathrm{l})$, but other circulating immunological markers were within normal limits (IgG $13.0 \mathrm{~g} / 1, \operatorname{IgM} 1.07 \mathrm{~g} / 1, \mathrm{IgD} 0.03 \mathrm{~g} / 1, \mathrm{IgE} 55 \mathrm{IU}$; lymphocyte t cells $86^{\circ}{ }_{0}$, B cells $12^{\circ}{ }^{\circ}$, IgG FcR $17^{\circ} ; \mathrm{CH}_{50}$ (haemolytic unit of complement yielding $50^{\circ}{ }_{0}$ lysis in complement fixation test) $39 \mathrm{U})$. The Mantoux reaction was negative. Histological examination of lung tissue obtained by transbronchial lung biopsy showed a non-caseating, epithelioid cell granuloma (fig 1), infiltration of the interstitium by small mononuclear cells, and Masson bodies, findings compatible with granulomatous interstitial pneumonia due to hypersensitivity pneumonitis.

Several days after admission the symptoms disappeared, and pulmonary function returned to normal (VC $92 \%$ predicted, TLCo $82 \%$ predicted, $\mathrm{PaO}_{2} 11 \cdot 3 \mathrm{kPa}$ ). The abnormal shadows on the chest radiograph had cleared three weeks after admission. As these findings suggested acute type hypersensitivity pneumonitis we investigated the antigenic substances that could have initiated this.

Several immunological tests and inhalation tests were performed with silkworm antigen, moulds, and organic dust. Silkworm antigen was made as previously described. ${ }^{12}$ In brief, secretions from ripe larvae were collected, suspended in water, and filtered with No 2 filter paper. After extraction with $90 \%$ saturated ammonium sulphate the precipitate was dialysed against water and alcohol was added to the sediment and mixed for 48 hours. The final alcohol precipitate was lyophilised, resuspended with water at a concentration of 


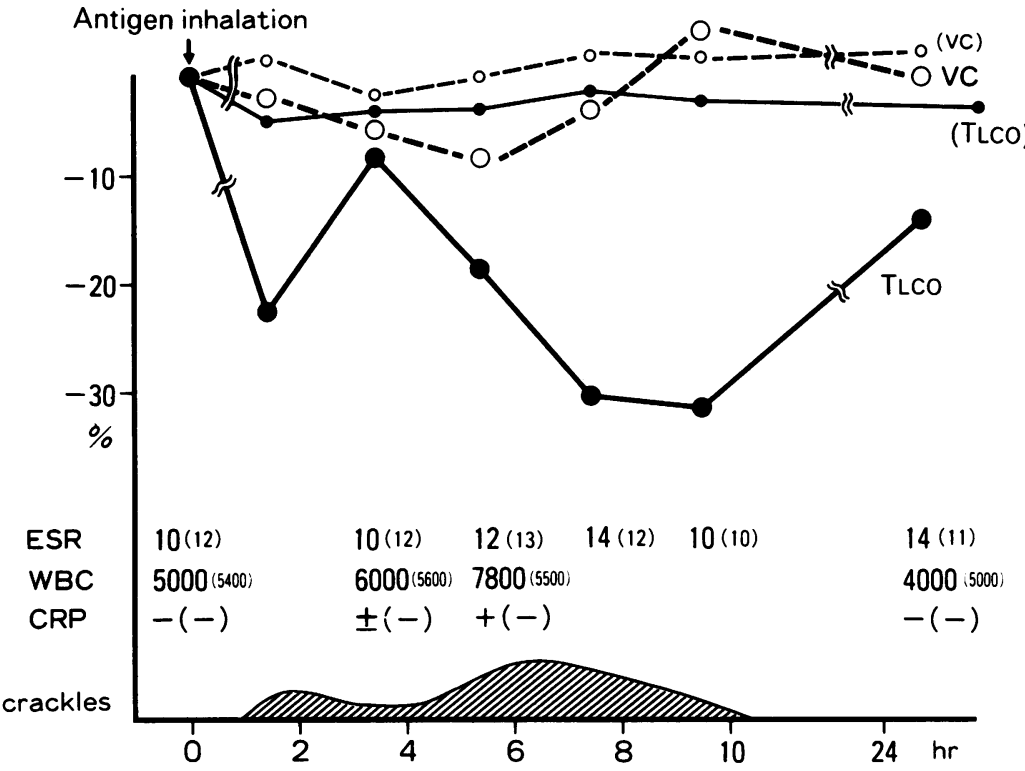

Figure 2 Results of inhalation tests using $5 \mathrm{mg}$ of silkworm antigen extract in the patient and a healthy, unexposed subject (values in parentheses). The values for erythrocyte sedimentation rate (ESR), white blood cell count (WBC), and $C$ reactive protein (CRP) are those obtained from the patient. The healthy subject showed no change in ESR (range 10-13) or WBC (5000-5 400) and no C reactive protein at any time of measurement. VC-vital capacity; TLCO-carbon monoxide transfer factor. Conversion to SI units-white blood cell count: $5000 / \mathrm{mm}^{3}=5.0 \times 10^{9} / \mathrm{l}$

$5 \mathrm{mg} / \mathrm{ml}$, and used as silkworm antigen. The silkworm antigen was considered not to be contaminated by moulds or organic dusts because double gel diffusion with anti-silkworm antigen rabbit serum gave a positive reaction to silkworm antigen, whereas other organic antigens gave negative results. Precipitins against silkworm antigen $(5 \mathrm{mg} / \mathrm{ml})$ were present in serum from the patient, but precipitins against other moulds and organic dusts known to cause hypersensitivity pneumonitis were not present.

Six hours after the patient inhaled $5 \mathrm{mg}$ of the silkworm antigen she developed fine crackles in the chest, slight leucocytosis, positive conversion of $\mathrm{C}$ reactive protein, and a $30 \%$ fall in TLCO (fig 2). These findings did not develop when a healthy, non-exposed subject inhaled the same antigen extract (fig 2).

\section{Discussion}

The clinical symptoms, histological findings, and laboratory findings in our patient were consistent with the diagnosis of hypersensitivity pneumonitis. The initiating antigen appeared to be dervied from silkworms. Our patient had serum precipitins against silkworm antigen, but not other organic antigens known to produce this disease. Silkworm antigen inhalation did not reproduce all the symptoms perfectly, but it did cause a fall in TLCO and VC and the appearance of crackles and $\mathrm{C}$ reactive protein. Previous reports suggest that inhalation of low doses of antigen produce a fall in TLCo only, whereas high doses produce more typical findings of hypersensitivity pneumonitis. ${ }^{3}$ Inhalation of silkworm antigen did not produce abnormal results in a non-exposed healthy subject, suggesting that the abnormalities in our patient were not a non-specific effect of antigen inhalation. No contaminants were detected in the silkworm antigen. These findings suggest that the disease in this patient was hypersensitivity pneumonitis due to the body constituents of silkworm.

Hypersensitivity pneumonitis has been described in relation to various occupations from inhalation of antigenic substances. ${ }^{4-7}$ Our study suggests that silkworm antigen induces hypersensitivity pneumonitis. We suggest that this disease should be called "sericulturist's lung disease."

1 Kobayashi S. Studies on antigenic substances in sericulture. Jap Clin Immunol 1970;2/4:447-50.

2 Nakazawa S. Studies on bronchial asthma due to Mabushi. Kitakantou-Igaku (Jap) 1959;13:497-512.

3 Toyama J, Nakamata M, Kondo A, Arakawa M. A case of hypersensitivity pneumonitis due to Aspergillus fumigatus. Nihon kyobusikkan gakkaisi 1981;19:402-8.

4 Salvaggio JE, Karr RM Hypersensitivity pneumonitis. Chest 1979;75:270-80.

5 Roberts RC, Moore VL. Immunopathogenesis of hypersensitivity pneumonitis. Am Rev Respir Dis 1977;116 1075-81.

6 Shatz M, Patterson R, Fink J. Immunopathogenesis of hypersensitivity pneumonitis. J Allergy Clin Immunol 1977;60:27-36.

7 Sakula A. A mushroom worker's lung. $B r$ Med J 1967;iii: 708-10. 